University of Windsor

Scholarship at UWindsor

2013

\title{
Baseline Corticosterone in Wintering Marine Birds: Methodological Considerations and Ecological Patterns
}

\author{
E. C. Palm \\ University of Windsor \\ D. Esler \\ University of Windsor \\ E. M. Anderson \\ University of Windsor \\ Tony D. Williams \\ University of Windsor \\ O. P. Love \\ University of Windsor
}

See next page for additional authors

Follow this and additional works at: https://scholar.uwindsor.ca/biologypub

Part of the Biology Commons

\section{Recommended Citation}

Palm, E. C.; Esler, D.; Anderson, E. M.; Williams, Tony D.; Love, O. P.; and Wilson, M. T., "Baseline Corticosterone in Wintering Marine Birds: Methodological Considerations and Ecological Patterns" (2013). Physiological \& Biochemical Zoology, 86, 3, 346-353.

https://scholar.uwindsor.ca/biologypub/1042

This Article is brought to you for free and open access by the Department of Biological Sciences at Scholarship at UWindsor. It has been accepted for inclusion in Biological Sciences Publications by an authorized administrator of Scholarship at UWindsor. For more information, please contact scholarship@uwindsor.ca. 


\section{Authors}

E. C. Palm, D. Esler, E. M. Anderson, Tony D. Williams, O. P. Love, and M. T. Wilson 


\section{Baseline Corticosterone in Wintering Marine Birds: Methodological Considerations and Ecological Patterns}

\author{
E. C. Palm ${ }^{1, *}$ \\ D. Esler ${ }^{1}$ \\ E. M. Anderson ${ }^{1}$ \\ T. D. Williams ${ }^{1}$ \\ O. P. Love ${ }^{2}$ \\ M. T. Wilson ${ }^{3}$ \\ ${ }^{1}$ Centre for Wildlife Ecology, Simon Fraser University, 8888 \\ University Drive, Burnaby, British Columbia V5A 1S6, \\ Canada; ${ }^{2}$ Department of Biological Sciences, University of \\ Windsor, 401 Sunset Avenue, Windsor, Ontario N9B 3P4, \\ Canada; ${ }^{3}$ US Fish and Wildlife Service, Fairbanks Fish and \\ Wildlife Field Office, 101 12th Avenue, Fairbanks, Alaska 99701
}

Accepted 2/4/2013; Electronically Published 3/26/2013

\begin{abstract}
Previous studies have related levels of plasma corticosterone (CORT) of seabirds to variation in foraging conditions during the breeding period, but it is unclear whether similar relationships between foraging conditions and baseline CORT exist during other life stages. We validated methods for identifying baseline CORT of lethally sampled birds and assessed variation in baseline CORT relative to winter habitat conditions. We collected free-living white-winged scoters (Melanitta fusca) at four wintering sites during December and February. We found increasing CORT values beyond $3 \mathrm{~min}$ after time since flush (the duration between initial flush and death), presumably reflecting acute stress responses. Our results demonstrate that it is possible to obtain baseline CORT from lethally sampled birds if the time from initial flush until death is measured. Our study sites varied appreciably in exposure to wind and waves, predation danger, diving depths, and the fraction of preferred foods in scoter diets. Despite these habitat differences, baseline CORT did not vary across sites or winter periods. We interpret this lack of variation as evidence that birds select wintering areas where they can successfully manage site-specific costs and maintain physiological homeostasis.
\end{abstract}

\footnotetext{
* Corresponding author; e-mail: epalm@sfu.ca.
}

Physiological and Biochemical Zoology 86(3):346-353. 2013. (C) 2013 by The University of Chicago. All rights reserved. 1522-2152/2013/8603-2078\$15.00. DOI: $10.1086 / 670156$

\begin{abstract}
Introduction
Plasma corticosterone (CORT) increasingly has been used as a tool to infer local habitat conditions for many vertebrate species and to contrast relative condition of individuals and populations (Kitaysky et al. 1999; Homan et al. 2003; Walker et al. 2005; Wikelski and Cooke 2006; Bonier et al. 2009). Secretion of plasma CORT quickly increases responses to temporary stressors, such as a predatory attack, severe storms, or capture by researchers (Breuner et al. 2008). However, behavioral and physiological effects of an acute stress response are markedly different from those associated with variation in baseline CORT. Baseline levels of CORT are those that are sufficient for animals to carry out normal physiological functions and maintain energetic balance (Romero 2004). Baseline levels may increase in response to prolonged environmental challenges, such as decreased food availability, increased predation danger, or increased frequency of inclement weather (Kitaysky et al. 1999; Clinchy et al. 2004). Increased baseline CORT is correlated with increased foraging, movement, and mobilization of energy reserves and is thus presumed to be an adaptation for overcoming environmental stressors (Sapolsky et al. 2000; Landys et al. 2006; Angelier et al. 2007). However, chronically elevated concentrations of plasma CORT can negatively affect fitness (Romero
\end{abstract} 2004).

There are many studies describing variation in baseline CORT in free-living birds. This research shows that baseline CORT may vary with environmental conditions or endogenously over time. Some diurnal species exhibit pronounced daily rhythms in CORT levels in captivity and in the wild, with peak levels occurring in the morning hours, often at or just prior to the onset of activity (Westerhof et al. 1994; Breuner et al. 1999; Romero and Remage-Healey 2000; Tarlow et al. 2003). Because CORT helps regulate acquisition, mobilization, and deposition of energy, a peak in CORT levels near dawn may help prepare birds for energetic demands immediately before feeding (Breuner et al. 1999). Elevated baseline CORT also can drive accumulation of energetic stores in preparation for long-distance migration (Holberton et al. 1999; Reneerkens et al. 2002). Research on some wintering passerines shows consistently lower CORT concentrations across a wide geographical area during winter compared to levels during spring migration and breeding, suggesting that seasonal fluctuations may be endogenously regulated rather than in response to local habitat conditions (Romero et al. 1997). In seabirds, baseline CORT can increase as food availability declines (Kitaysky et al. 1999; Buck et al. 2007). These findings have prompted researchers to suggest that baseline CORT could be used as a proxy for food availability (Buck et al. 2007; Kitaysky et al. 2007). How- 
ever, most studies relating plasma CORT in seabirds to foraging conditions have focused on the breeding period (Romero 2002), and it is unclear whether similar relationships between foraging conditions and baseline CORT exist during other life stages.

Measuring blood plasma levels of baseline CORT in the field is challenging because capture and bleeding are stressors that can result in acute stress responses (Romero and Romero 2002). The relationship between time since capture and acute CORT response has been well documented, and it is clear that CORT levels rise within minutes of exposure to stressors; thus, accurate assessment of baseline CORT requires that time between capture and bleeding be below the point at which acute CORT responses are detected (Wingfield et al. 1982; Romero and Romero 2002; Romero and Reed 2005).

In some species (e.g., open-water seabirds) or during particular stages of the annual cycle, lethal sampling may be the only viable means to collect blood samples. Such sampling eliminates stress associated with capture and handling, but approaching or pursuing birds also may result in acute stress. However, the few studies that have published CORT data from lethally collected birds have not assessed changes in CORT levels as a function of the time between initial disturbance and death (Lisano et al. 1977; Whatley et al. 1977; Wingfield et al. 1982; Marra et al. 1995).

White-winged scoters (Melanitta fusca) are sea ducks that spend most of the year in marine habitats. Although the British Columbia (BC) coastline entails a significant portion of their wintering range on the Pacific coast of North America, there are few wintering areas in $\mathrm{BC}$ where white-winged scoters occur in high concentrations (J.-P. L. Savard, unpublished data). This may be due in part to their preference for soft-bottom habitats with abundant bivalve foods, which are relatively uncommon in BC. However, even among such sites, there is considerable variation in habitat conditions that may affect baseline CORT levels of white-winged scoters. Widespread population declines in white-winged scoters and other sea duck species have prompted efforts to identify functional roles of different habitats used throughout the annual cycle by analyzing body condition, prey availability, foraging effort, diet composition, and plasma metabolite analyses (e.g., Žydelis et al. 2006; Anderson and Lovvorn 2008, 2011; Anderson et al. 2008; Lewis et al. 2008; Palm et al. 2012). Baseline CORT could complement these measures by providing additional insight into the relative values of different sea duck wintering habitats.

We measured plasma CORT levels in free-living whitewinged scoters that were lethally collected at four wintering areas along coastal BC (fig. 1). These sites varied markedly in terms of exposure, predation danger, diving depths, and the fraction of preferred foods in scoter diets (see below). Live capture of scoters at two of these sites was not feasible because they fed mainly in deep water $>5 \mathrm{~km}$ from shore. Thus, lethal collections entailed the only viable means of obtaining blood samples and also allowed for analyses of body composition, diet, and digestive morphology (Palm 2012; Palm et al. 2012). Our specific objectives were to delineate appropriate methods of identifying baseline CORT from lethally collected birds and

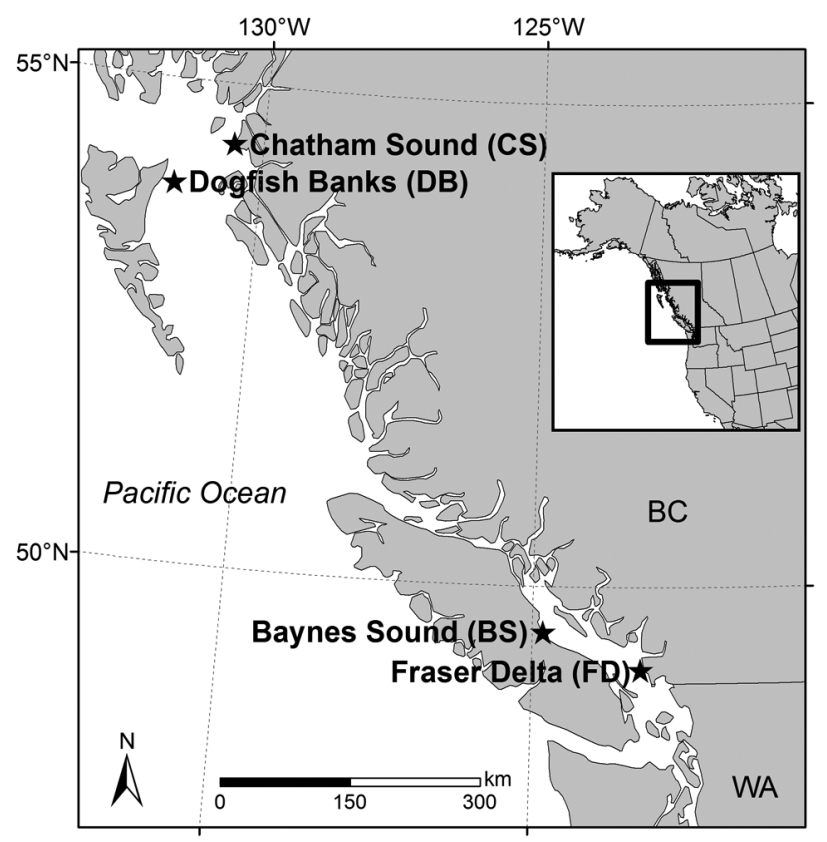

Figure 1. Map of four study sites along coastal British Columbia where studies of plasma CORT in wintering white-winged scoters were conducted during 2009-2011.

to assess variation in baseline CORT relative to winter habitat conditions. We predicted that in sites with less favorable foraging conditions white-winged scoters would have elevated levels of baseline CORT that would reflect the challenge of dealing with these poor conditions (Wasser et al. 1997; Suorsa et al. 2003) or help trigger behavioral and physiological adaptations to successfully cope with them (Wingfield and Ramenofsky 1997; Reneerkens et al 2002).

\section{Methods}

\section{Sample Collection}

We collected a total of 119 adult male white-winged scoters using a shotgun from a small boat at four wintering areas along coastal BC (fig. 1), under the authority of permits from Environment Canada (BC-09-0182) and Simon Fraser University Animal Care (992B-06). There were a total of eight collection events across the four sites: Dogfish Banks (December 2009 $[N=20]$ and February $2010[N=18]$ ), Chatham Sound (December $2009[N=13]$ and February $2010[N=10])$, Fraser River Delta (December $2010[N=13]$ and February 2011 $[N=15]$ ), and Baynes Sound (December $2010[N=15]$ and February $2011[N=15])$. By conducting all collections before the end of February, we assumed that any differences in baseline CORT among wintering areas would be a result of variation in local habitat conditions rather than physiological changes associated with spring migration, which does not occur until April or later (W. S. Boyd, unpublished data).

To eliminate potential variation in baseline CORT related to age class or sex (Bonier et al. 2007; Wada et al. 2008), we 
collected only after-hatch-year (i.e., mature/adult) males as verified by plumage (Brown and Fredrickson 1997). We recorded the time since flush for each bird, which we defined as the period between initial flush and death. Because of the difficulty of determining when a bird first began to respond to our presence on our approach, times since flush were estimated and rounded to the nearest whole minute. We generally approached small flocks at speeds of 15-25 knots and shot flying birds from a moving boat. We made all efforts to ensure that all birds were killed cleanly and quickly. Within 5 min of retrieval, we sampled heart blood using a sterile 18-gauge needle and transferred up to $5 \mathrm{~mL}$ of blood to a heparinized vial for CORT analyses. We centrifuged whole blood within $8 \mathrm{~h}$ of collection to separate plasma and cells and stored all tissues at $-20^{\circ} \mathrm{C}$. To facilitate examination of relationships between CORT and metrics of individual condition, Long Point Waterfowl's Avian Energetics Lab (Port Rowan, Ontario) conducted analyses of body composition (total protein, lipid, water, and ash) from ingesta-free dry carcass mass, including plumage, following methods of Afton and Ankney (1991).

\section{CORT Assay}

We determined concentration of total CORT in nonextracted plasma using a corticosterone enzyme-linked immunoabsorbent assay (EIA-Assay Designs, catalog no. 901-097) with a four-parameter logistic fit based on Love and Williams (2008). We ran all samples in triplicate across six assay plates at a total volume of $100 \mu \mathrm{L}$ with $1: 40$ dilution and 1.5\% steroid displacement buffer. As per kit instructions, we first incubated plates at $26^{\circ} \mathrm{C}$ under shaking at $500 \mathrm{rpm}$ for $2 \mathrm{~h}$ and then at $26^{\circ} \mathrm{C}$ without shaking for $1 \mathrm{~h}$; we calculated the detection limit of the assay at $0.018 \mathrm{ng} /$ well $(0.72 \mathrm{ng} / \mathrm{mL})$, with intra- and interassay coefficients of variation of $6.89 \%$ and $10.15 \%$, respectively.

\section{Study Sites}

Each study site (fig. 1) represented a different combination of three habitat conditions, which we assessed for their influence on baseline CORT: exposure to wind and waves, water depth, and predation danger (table 1). Along the Pacific Coast, many white-winged scoters winter in somewhat protected nearshore areas. Dogfish Banks $\left(53^{\circ} 55^{\prime} \mathrm{N}, 131^{\circ} 30^{\prime} \mathrm{W}\right)$ is a notable exception because it is an offshore site that is particularly susceptible to turbulent seas during winter storms due to frequent high winds from the southeast (RPS Energy 2009). Combined with a mobile substrate of sand or a sand-gravel mixture, these conditions result in a frequently changing benthic foraging habitat. At Dogfish Banks, there is virtually no presence of bald eagles (Haliaeetus leucocephalus), which are the most likely predator of white-winged scoters (Anderson et al. 2012). Relative to other study sites, Dogfish Banks birds feed on a more diverse suite of prey (Palm et al. 2012). Water depths at the study site range from 4 to $20 \mathrm{~m}$, and the maximal tidal range is approximately $5 \mathrm{~m}$ (Amos et al. 1995).

Situated among many large islands and the mainland coast, Chatham Sound $\left(54^{\circ} 27^{\prime} \mathrm{N}, 130^{\circ} 25^{\prime} \mathrm{W}\right)$ is more protected from high winds and large swells than Dogfish Banks. Birds at Chatham Sound feed in deep water $(5-30 \mathrm{~m})$, searching for prey in sandy and muddy substrate situated between rock outcrops (E. Palm, personal observation). Bivalves are the main prey taken by white-winged scoters at this site, but during some periods, birds at Chatham Sound consume a wider variety of foods, including echinoderms and crustaceans (Palm et al. 2012).

Baynes Sound $\left(49^{\circ} 39^{\prime} \mathrm{N}, 124^{\circ} 53^{\prime} \mathrm{W}\right)$ contains extensive intertidal flats and high densities of wild and cultured bivalves, providing nearshore habitat for about 6,500 white-winged and surf scoters during winter (W. S. Boyd, unpublished data). Because it provides an abundant and temporally stable source of bivalve prey and white-winged scoters wintering in the area show relatively low foraging effort, Baynes Sound is thought to be high-quality foraging habitat (Lewis et al. 2007, 2008). Unlike on Dogfish Banks, white-winged scoters wintering on Baynes Sound and Chatham Sound often forage in close proximity to high densities of bald eagles.

Thousands of white-winged scoters use the shallow intertidal mudflats on the Fraser River Delta $\left(49^{\circ} 06^{\prime} \mathrm{N}, 123^{\circ} 16^{\prime} \mathrm{W}\right)$ annually for molting, wintering, and staging (J. R. Evenson, unpublished data). The Fraser River Delta offers very few potential perches for bald eagles. Similar to scoter diets in Baynes Sound, diets on the Fraser River Delta consist almost entirely of bivalve prey (Palm et al. 2012).

\section{Data Analysis}

Quantification of Time Line to Acute Stress. Before running the models corresponding to each of our a priori hypotheses describing possible sources of variation in baseline CORT, we

Table 1: Variation in habitat conditions and diet composition among four wintering sites for white-winged scoters in British Columbia

\begin{tabular}{lllll}
\hline Study site & Exposure & $\begin{array}{l}\text { Water } \\
\text { depth }\end{array}$ & $\begin{array}{c}\text { Proportion of } \\
\text { bivalves in diet }\end{array}$ & $\begin{array}{c}\text { Predation } \\
\text { danger }\end{array}$ \\
\hline Chatham Sound & Low & High & High to very high & High \\
Dogfish Banks & High & High & Medium to high & Low \\
Baynes Sound & Low & Low & Very high & High \\
Fraser River Delta & Low & Low & Very high & Low \\
\hline
\end{tabular}


quantified the time between initial flush of targeted birds and acute stress response, represented by an increase in plasma CORT concentration. We excluded a single data point from all analyses, with a CORT concentration of $151.3 \mathrm{ng} / \mathrm{mL}$ and an associated time since flush of $1 \mathrm{~min}$, because it far exceeded baseline values found in a separate study of wintering sea ducks, which ranged from approximately 15 to $50 \mathrm{ng} / \mathrm{mL}$ (Nilsson et al. 2008). An initial plot of CORT versus time since flush showed average CORT to be relatively stable until approximately 3-4 min, after which it increased (fig. 2). We ran a series of multiple linear regressions in $\mathrm{R}$ ( $\mathrm{R}$ Development Core Team 2011) to determine the appropriate cutoff time that would separate baseline values from values of potentially acutely stressed birds (Nickerson et al. 1989).

Using $1 \mathrm{~min}$ as the first potential cutoff time, we separated CORT data into two groups based on associated time since flush: (1) 0-1 min and (2) >1 min. For each of the two groups in the linear model, we allowed both the intercept and the slope to vary. We then repeated the process using every time since flush from 2 to 6 min as the potential cutoff time between the two groups. We expected to see a relatively flat line for baseline values, followed by a linear increase in CORT over time, which would represent acute stress. To choose the cutoff time that provided the best fits of both baseline CORT and the acute stress response, we calculated Akaike's Information Criterion adjusted for small sample size $\left(\mathrm{AIC}_{\mathrm{c}}\right.$ ) for each of the models and chose the model with the lowest value (Burnham and Anderson 2002). We log transformed CORT data to meet assumptions of normality in our linear models, but we report untransformed data.

Geographic Variation in Baseline CORT. Based on the analyses described above, we excluded birds for which time since flush exceeded the determined cutoff and thus may have exhibited acute CORT response. Eliminating these birds ensured that values included in subsequent analyses represented baseline levels. We compared baseline CORT data across study sites and collection periods using least squares analyses in an information-theoretic context. We pooled data from the eight separate collection events in specific ways to test relative support for different biologically plausible, a priori hypotheses describing possible sources of variation in baseline CORT. Exposure, water depth, diet composition, predation danger, and collection period were all factors potentially influencing baseline CORT, and these factors varied across study sites (table 1). To account for the potential effect of collection period (December vs. February), we included models that pooled data based on period in addition to another factor. For example, if the hypothesis was that baseline CORT varied by water depth and period, the explanatory variable would have four levels: (1) midwinter deep-water sites, (2) midwinter shallow-water sites, (3) latewinter deep-water sites, and (4) late-winter shallow-water sites. In addition, we included a null model, representing the hypothesis that CORT did not vary geographically or by collection period. To account for assumed daily fluctuation in CORT levels, time of day was a covariate in all models except the null.

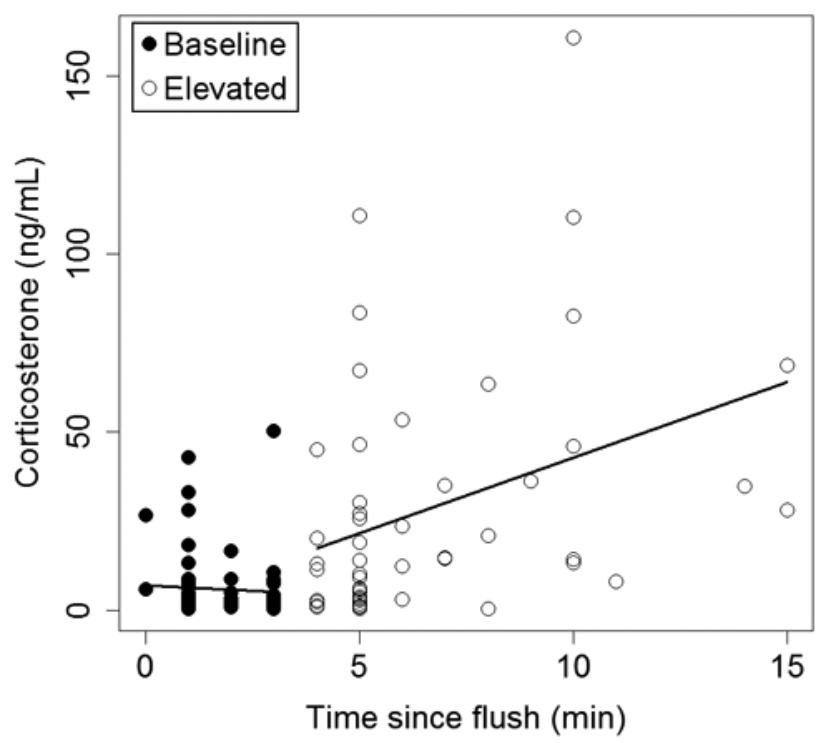

Figure 2. Plasma CORT concentrations as a function of time since flush (i.e., the period between initial flush and death). Separate regression lines for baseline levels ( $0-3 \mathrm{~min}$ ) and elevated levels ( $>3 \mathrm{~min}$ ) were derived from the best-supported model evaluating appropriate cutoff time.

We also included a model with time of day as the only explanatory variable. Below, we describe and justify our predictions for effects of three habitat factors, diet composition, and time of day on baseline CORT.

Exposure. At more exposed sites, baseline CORT in seabirds may vary in response to a greater frequency in storms, which can limit access to food resources (Smith et al. 1994). For the exposure hypotheses, we pooled Dogfish Banks data separately from data from other sites (table 2).

Water Depth. Increased baseline CORT may trigger increased explorative behavior for locating food (Reneerkens 2002). At greater depths, where locating benthic prey may require more time and effort, such a behavioral response could be beneficial for white-winged scoters. Alternatively, an increase in explorative behavior at some sites may induce increased baseline CORT. To group CORT data by water depth, we pooled data from Dogfish Banks and Chatham Sound separately from the remaining two sites (table 2 ).

Predation Danger. Increased predation danger has been associated with increased baseline CORT in a number of bird species (Scheuerlein et al. 2001; Cockrem and Silverin 2002; Hawlena and Schmitz 2010). For the predation danger hypotheses, we pooled Fraser River Delta and Dogfish Banks data separately from Baynes Sound and Chatham Sound (table 2).

Diet Composition. Diet composition can be used as another indicator of the availability of food resources in that area, which 
Table 2: Candidate models describing variation in baseline levels of plasma CORT in male white-winged scoters across four wintering areas in British Columbia

\begin{tabular}{|c|c|c|c|c|c|}
\hline Explanatory variable & Site and period grouping & $K$ & $\Delta \mathrm{AIC}_{\mathrm{c}}$ & $w$ & $r^{2}$ \\
\hline Time-of-day covariate only & $\mathrm{CS}=\mathrm{DB}=\mathrm{BS}=\mathrm{FD}$ & 3 & .00 & .31 & .04 \\
\hline Null & $\mathrm{CS}=\mathrm{DB}=\mathrm{BS}=\mathrm{FD}$ & 2 & .82 & .21 & $\ldots$ \\
\hline Diet composition & $\mathrm{CSM}=\mathrm{DB} ; \mathrm{CSL}=\mathrm{BS}=\mathrm{FD}$ & 4 & .87 & .20 & .06 \\
\hline Predation danger & $\mathrm{CS}=\mathrm{BS} ; \mathrm{DB}=\mathrm{FD}$ & 4 & 1.21 & .17 & .06 \\
\hline Water depth & $\mathrm{CS}=\mathrm{DB} ; \mathrm{BS}=\mathrm{FD}$ & 4 & 1.80 & .13 & .05 \\
\hline Period & $\mathrm{CSM}=\mathrm{DBM}=\mathrm{BSM}=\mathrm{FDM} ; \mathrm{CSL}=\mathrm{DBL}=\mathrm{BSL}=\mathrm{FDL}$ & 4 & 2.01 & .12 & .05 \\
\hline Exposure & $\mathrm{DB} ; \mathrm{CS}=\mathrm{BS}=\mathrm{FD}$ & 4 & 2.22 & .10 & .05 \\
\hline Exposure, period & $\mathrm{CSM}=\mathrm{BSM}=\mathrm{FDM} ; \mathrm{CSL}=\mathrm{BSL}=\mathrm{FDL} ; \mathrm{DBM} ; \mathrm{DBL}$ & 6 & 4.84 & .03 & .07 \\
\hline Water depth, period & $\mathrm{CSM}=\mathrm{DBM} ; \mathrm{CSL}=\mathrm{DBL} ; \mathrm{BSM}=\mathrm{FDM} ; \mathrm{BSL}=\mathrm{FDL}$ & 6 & 5.44 & .02 & .07 \\
\hline Predation danger, period & $\mathrm{CSM}=\mathrm{BSM} ; \mathrm{CSL}=\mathrm{BSL} ; \mathrm{DBM}=\mathrm{FDM} ; \mathrm{DBL}=\mathrm{FDL}$ & 6 & 5.64 & .02 & .06 \\
\hline
\end{tabular}

Note. $\mathrm{BS}=$ Baynes Sound; $\mathrm{CS}=$ Chatham Sound; $\mathrm{DB}=$ Dogfish Banks; FD = Fraser River Delta; $\mathrm{M}=$ midwinter; $\mathrm{L}=$ late winter. Results account for inclusion of a covariate for time of day for all models except the null.

can influence baseline CORT levels (Reneerkens et al. 2002). We grouped CORT data from both December and February at Dogfish Banks with February CORT data from Chatham Sound in our examination of the diet composition hypotheses (table 2).

\section{Post Hoc Analysis}

Based on past studies that found relationships between baseline CORT and measures of body condition (Kitaysky et al. 1999; Müller et al. 2007), we ran a post hoc analysis to test the hypotheses that baseline CORT varied by body mass, lipid mass, or protein mass. Structural body size, which we estimated separately using measurements of culmen, wing cord, tarsus, and the first principal component of all three, explained $<16 \%$ of variation in body mass and was not correlated with total lipid mass (all $r^{2}<0.06$ ) or total protein mass (all $r^{2}<0.03$ ). Therefore, we did not correct measures of individual condition for body size. We included time of day as a covariate in all models except the null.

\section{Model Selection}

We used information-theoretic methods to direct model selection and used R (R Development Core Team 2011) for all statistical analyses. To infer the relative support of each model included in the candidate set, we calculated $\mathrm{AIC}_{c}, \Delta \mathrm{AIC}_{\mathrm{c}}$ values, and Akaike weights ( $w$; Burnham and Anderson 2002). Both $\Delta \mathrm{AIC}_{\mathrm{c}}$ and $w$ values measure the relative amount of support for each model compared to other models in the candidate set.

\section{Results}

\section{Quantification of Time Line to Acute Stress}

The model using $3 \mathrm{~min}$ as the cutoff time $\left(r^{2}=0.31\right)$ to separate baseline values from values representing acute stress provided the best fit of the observed data. Therefore, we excluded all CORT values with associated time since flush $(t)$ of $>3 \mathrm{~min}$ in subsequent analyses. The regression equations (parameter estimates [SE]) for this model reflected our expectation that baseline CORT values would form a relatively flat line below a certain time since flush (3 $\mathrm{min})$, after which CORT would increase linearly, corresponding to acute stress (fig. 2):

$$
\begin{aligned}
\text { baseline CORT } & =6.97(5.55)-0.61(3.01) t \\
\text { collected after } 3 \mathrm{~min} & =0.39(9.65)+4.24(3.20) t .
\end{aligned}
$$

\section{Geographic Variation in Baseline CORT}

Across all sites, average $( \pm \mathrm{SE})$ baseline CORT was $6.64 \pm$ $1.19 \mathrm{ng} / \mathrm{mL}$. Five models describing variation in baseline CORT had $\Delta \mathrm{AIC}_{\mathrm{c}}$ scores $\leq 2$, with the most parsimonious model being that with the time-of-day covariate only. We observed a negative relationship between baseline CORT and time of day, which is consistent with past research on daily rhythms of CORT in diurnal birds. After accounting for the effect of time of day, the null model was the next most supported model $(w=$ 0.21), indicating similar CORT levels across sites and periods. Overall, $>92 \%$ of the variation in CORT was not explained by any of the models in our candidate set (table 2). There was no evidence indicating that exposure, water depth, predation danger, or diet composition influenced baseline CORT. In addition, baseline CORT did not differ between December and February. In our post hoc analyses examining relationships between individual condition and baseline CORT, all three measures of condition outperformed the null model, while both protein mass and body mass models outperformed the model with the time-of-day covariate only (table 3 ). The protein mass model was most parsimonious, explaining $18 \%$ of the variation in baseline CORT. The correlation between protein mass and baseline CORT suggested that elevated CORT was associated with lower protein mass.

\section{Discussion}

Our results demonstrate that it is possible to measure baseline CORT levels from lethally collected birds if the time from initial 
Table 3: Post hoc candidate models describing variation in baseline levels of plasma CORT in male white-winged scoters across four wintering areas in British Columbia

\begin{tabular}{lcccc}
\hline Explanatory variable & $K$ & $\Delta \mathrm{AIC}_{\mathrm{c}}$ & $w$ & $r^{2}$ \\
\hline Protein mass & 4 & .00 & .89 & .18 \\
Body mass & 4 & 5.02 & .07 & .11 \\
Time-of-day & & & & \\
$\quad$ covariate only & 3 & 7.86 & .02 & .04 \\
Lipid mass & 4 & 8.33 & .01 & .07 \\
$\quad$ Null & 2 & 8.68 & .01 & $\ldots$ \\
\hline
\end{tabular}

Note. Results account for inclusion of a covariate for time of day for all models except the null.

flush until death is measured. We found increasing CORT values above a time since flush of $3 \mathrm{~min}$, presumably reflecting acute stress responses. That result is consistent with past studies indicating that blood samples taken within $3 \mathrm{~min}$ of capture represented baseline CORT (Wingfield et al. 1982; Romero et al. 1997; Silverin and Wingfield 1998; Romero and Romero 2002; Romero and Reed 2005). Our methods, which determined the appropriate cutoff time between baseline and stressed concentrations of CORT in shot birds, can be applied in subsequent studies requiring lethal sampling of birds.

Despite differences in habitat conditions, baseline CORT of white-winged scoters did not differ across sites. These results suggest three possibilities: (1) overall foraging conditions were not markedly different among our study sites, (2) fluctuations in baseline CORT levels were largely endogenously regulated and dependent on season, or (3) baseline CORT was not affected by the habitat factors we considered. If baseline CORT levels in wintering white-winged scoters were driven primarily by unfavorable foraging conditions, values should have been greatest at Dogfish Banks because of its frequent storms, strong currents, mobile substrate (RPS Energy 2009), and relatively low dietary fraction of bivalves (Palm et al. 2012).

Combining baseline CORT with data on body condition may provide more insight into differences in habitat conditions than either metric on its own (Kitaysky et al. 1999). White-winged scoters employed different energy management strategies across sites on the basis of habitat conditions. Wintering birds at Dogfish Banks maintained relatively high lipid mass, which likely functioned as a buffer against frequently changing foraging conditions (Palm 2012). During both December and February, average lipid mass at Dogfish Banks was more than twice as high as at Baynes Sound, which has an abundant, predictable source of prey and more favorable weather (Lewis et al. 2008). Consistent with baseline CORT, levels of plasma metabolites varied little across sites, suggesting that, irrespective of body composition, birds at all sites maintained physiological homeostasis (Palm 2012). Our results suggest that individual condition of birds may have influenced baseline CORT; however, irrespective of their energy management strategy, birds were largely successful in maintaining homeostasis and avoiding physiological stress across sites.
Site selection based on physiological phenotype also may have contributed to the relatively low variation in baseline CORT across sites. In waterfowl, there is evidence that adult male birds often compose high proportions of populations that winter in northern sites or sites with relatively harsh weather (Jorde et al. 1984; D. Esler, unpublished data). The larger body size of male white-winged scoters relative to that of females confers lower mass-specific energy demands, making males better equipped to handle cold or windy environments (Goudie and Ankney 1986). Larger birds also may be more resistant to fluctuations in energy status as a result of variable foraging conditions (Richman and Lovvorn 2009). Further, older, more experienced birds may be more likely to find food resources in an unpredictable foraging environment. Relative to other sites, we saw a higher ratio of adult males to other cohorts at Dogfish Banks. Similar baseline CORT levels across our study sites may indicate that white-winged scoters select wintering areas where they can successfully maintain physiological homeostasis and that site selection may depend on individual specific suitability. Also, unlike breeding birds, wintering birds have more opportunity to abandon a site if conditions deteriorate (Kirk et al. 2008), allowing them to select sites amenable to the maintenance of physiological homeostasis.

\section{Acknowledgments}

We thank C. Harris for providing technical help with the plasma CORT assays and K. Jaatinen for assistance in the field. This study was funded by Environment Canada, Naikun Wind Energy Group, Natural Resources Canada, and Simon Fraser University. The Centre for Wildlife Ecology provided logistical support. An NSERC operating grant supported O.P.L.

\section{Literature Cited}

Afton A.D. and C.D. Ankney. 1991. Nutrient-reserve dynamics of breeding lesser scaup: a test of competing hypotheses. Condor 93:89-97.

Amos C.L., J.V. Barrie, and J.T. Judge. 1995. Storm enhanced sand transport in a macrotidal setting, Queen Charlotte Islands, British Columbia, Canada. Pp. 53-68 in B.W. Flemming and A. Bartoloma, eds. Tidal signatures in modern and ancient sediments. Spec Publ Int Assoc Sedimentol 24:5368.

Anderson E.M., D. Esler, W.S. Boyd, J.R. Evenson, D.R. Nysewander, D.H. Ward, R.D. Dickson, B.D. Uher-Koch, C.S. VanStratt, and J.W. Hupp. 2012. Predation rates, timing, and predator composition for scoters (Melanitta spp.) in marine habitats. Can J Zool 90:42-50.

Anderson E.M. and J.R. Lovvorn. 2008. Gray whales may increase feeding opportunities for avian benthivores. Mar Ecol Prog Ser 360:291-296.

- 2011. Contrasts in energy status and foraging strategies of white-winged scoters (Melanitta fusca) and surf scoters (M. perspicillata). Auk 128:248-257. 
Anderson E.M., J.R. Lovvorn, and M.T. Wilson. 2008. Reevaluating marine diets of surf and white-winged scoters: interspecific differences and the importance of soft-bodied prey. Condor 110:285-295.

Angelier F., S.A. Shaffer, H. Weimerskirch, C. Trouve, and O. Chastel. 2007. Corticosterone and foraging behavior in a pelagic seabird. Physiol Biochem Zool 80:283-292.

Bonier F., P.R. Martin, I.T. Moore, and J.C. Wingfield. 2009. Do baseline glucocorticoids predict fitness? Trends Ecol Evol 24:634-642.

Bonier F., P.R. Martin, K.S. Sheldon, J.P. Jensen, S.L. Foltzand, and J.C. Wingfield. 2007. Sex-specific consequences of life in the city. Behav Ecol 18:121-129.

Breuner C.W., S.H. Patterson, and T.P. Hahn. 2008. In search of relationships between the acute adrenocortical response and fitness. Gen Comp Endocrinol 157:288-295.

Breuner C.W., J.C. Wingfield, and L.M. Romero. 1999. Diel rhythms of basal and stress-induced corticosterone in a wild, seasonal vertebrate, Gambel's white-crowned sparrow. J Exp Zool 284:334-342.

Brown P.W. and L.H. Fredrickson. 1997. White-winged scoter (Melanitta fusca). Pp. 274 in A. Poole and F. Gill, eds. The birds of North America. Academy of Natural Sciences, Philadelphia/American Ornithologists' Union, Washington, DC.

Buck C.L., K.M. O’Reilly, and S.D. Kildaw. 2007. Interannual variability of black-legged kittiwake productivity is reflected in baseline plasma corticosterone. Gen Comp Endocrinol 150:430-436.

Burnham K.P. and D.R. Anderson. 2002. Model selection and multimodel inference: a practical information theoretic approach. Springer, New York.

Clinchy M., L. Zanette, R. Boonstra, J.C. Wingfield, and J.N.M. Smith. 2004. Balancing food and predator pressure induces chronic stress in songbirds. Proc R Soc B 271:2473-2479.

Cockrem J.F. and B. Silverin. 2002. Sight of a predator can stimulate a corticosterone response in the great tit (Parus major). Gen Comp Endocrinol 125:248-255.

Goudie R.I. and C.D. Ankney. 1986. Body size, activity budgets, and diets of sea ducks wintering in Newfoundland. Ecology 67:1475-1482.

Jorde D.G., G.L. Kropu, R.D. Crawford, and M.A. Hay. 1984. Effects of weather on habitat selection and behavior of mallards wintering in Nebraska. Condor 86:258-265.

Hawlena D. and O.J. Schmitz. 2010. Physiological stress as a fundamental mechanism linking predation to ecosystem functioning. Am Nat 175:537-556.

Holberton R.L. 1999. Changes in patterns of corticosterone secretion concurrent with migratory fattening in a Neotropical migratory bird. Gen Comp Endocrinol 116:49-58.

Homan R.N., J.M. Reed, and L.M. Romero. 2003. Corticosterone concentrations in free-living spotted salamanders ( Ambystoma maculatum). Gen Comp Endocrinol 130:165-171.

Kirk M., D. Esler, S.A. Iverson, and W.S. Boyd. 2008. Movements of wintering surf scoters: predator responses to different prey landscapes. Oecologia 155:859-867.

Kitaysky A.S., J.F. Piatt, and J.C. Wingfield. 2007. Stress hor- mones link food availability and population processes in seabirds. Mar Ecol Prog Ser 342:245-258.

Kitaysky A.S., J.C. Wingfield, and J.F. Piatt. 1999. Dynamics of food availability, body condition and physiological stress response in breeding black-legged kittiwakes. Funct Ecol 13: 577-584.

Landys M.M., M. Ramenofsky, and J.C. Wingfield. 2006. Actions of glucocorticoids at a seasonal baseline as compared to stress related levels in the regulation of periodic life processes. Gen Comp Endocrinol 148:132-149.

Lewis T.L., D. Esler, and W.S. Boyd. 2007. Effects of predation by sea ducks on clam abundance in soft-bottom intertidal habitats. Mar Ecol Prog Ser 329:131-144.

- 2008. Foraging behaviors of surf and white-winged scoters in relation to clam density: inferring food availability and habitat quality. Auk 125:149-157.

RPS Energy. 2009. Environmental assessment application for the Naikun offshore wind energy project: marine physical environment. Technical vol. 3, 87 pp.

Lisano M.E. and J.E. Kennamer. 1977. Seasonal variations in plasma testosterone level in male eastern wild turkeys. J Wildl Manag 41:184-188.

Love O.P. and T.D. Williams. 2008. Plasticity in the adrenocortical response of a free-living vertebrate: the role of preand post-natal developmental stress. Horm Behav 54:496505.

Marra P.P., K.T. Lampe, and B.L. Tedford. 1995. Plasma corticosterone levels in two species of Zonotrichia sparrows under captive and free-living conditions. Wilson Bull 107:296305.

Müller C., S. Jenni-Eiermann, J. Blondel, P. Perret, S.P. Caro, M.M. Lambrechts, and L. Jenni. 2007. Circulating corticosterone levels in breeding blue tits Parus caeruleus differ between island and mainland populations and between habitats. Gen Comp Endocrinol 154:128-136.

Nickerson D.M., D.E. Facey, and G.D. Grossman. 1989. Estimating physiological thresholds with continuous 2-phase regression. Physiol Zool 62:866-887.

Nilsson P., T. Hollmén, S. Atkinson, K. Mashburn, P. Tuomi, D. Esler, D. Mulcahy, and D. Rizzolo. 2008. Effects of ACTH, capture, and short term confinement on glucocorticoid concentrations in harlequin ducks (Histrionicus histrionicus). Comp Biochem Physiol 149:275-283.

Palm E.C. 2012. Trophic, energetic, and physiological responses of wintering white-winged scoters (Melanitta fusca) to habitat variation. MS thesis. Simon Fraser University, Burnaby, British Columbia.

Palm E.C., D. Esler, E.M. Anderson, and M.T. Wilson. 2012. Geographic and temporal variation in diet of wintering white-winged scoters. Waterbirds 35:577-589.

R Development Core Team. 2011. R: a language and environment for statistical computing. R Foundation for Statistical Computing, Vienna. http://www.R-project.org.

Richman S.E. and J.R. Lovvorn. 2009. Predator size, prey size, and threshold food densities of diving ducks: does a common 
prey base support fewer larger animals? J Anim Ecol 78:10331042.

Reneerkens J., M. Ramenofsky, and T. Piersma. 2002. An experimental test of the relationship between temporal variability of feeding opportunities and baseline levels of corticosterone in a shorebird. J Exp Zool 293:81-88.

Romero L.M. 2002. Seasonal changes in plasma glucocorticoid concentrations in free-living vertebrates. Gen Comp Endocrinol 128:1-24.

2004. Physiological stress in ecology: lessons from biomedical research. Trends Ecol Evol 19:249-255.

Romero L.M., M. Ramenofsky, and J.C. Wingfield. 1997. Season and migration alters the corticosterone response to capture and handling in an arctic migrant, the white-crowned sparrow (Zonotrichia leucophrys gambelii). Comp Biochem Physiol C 116:171-177.

Romero L.M. and J.M. Reed. 2005. Collecting baseline corticosterone samples in the field: is under $3 \mathrm{~min}$ good enough? Comp Biochem Physiol A 140:73-79.

Romero L.M. and R. Remage-Healey. 2000. Daily and seasonal variation in response to stress in captive starlings (Sturnus vulgaris): corticosterone. Gen Comp Endocrinol 119:52-59.

Romero L.M. and R.C. Romero. 2002. Corticosterone responses in wild birds: the importance of rapid initial sampling. Condor 104:129-135.

Sapolsky R.M., L.M. Romero, and A.U. Munck. 2000. How do glucocorticosteroids influence stress responses? integrating permissive, suppressive, stimulatory and preparative actions. Endocrinol Rev 21:55-89.

Scheuerlein A., T. Van't Hof, and E. Gwinner. 2001. Predators as stressors? physiological and reproductive consequences of predation risk in tropical stonechats (Saxicola torquata axillaris). Proc R Soc B 270:799-803.

Silverin B. 1998. Territorial behaviour and hormones of pied flycatchers in optimal and suboptimal habitats. Anim Behav 56:811-818.

Smith G.T., J.C. Wingfield, and R.R. Veit. 1994. Adrenocortical response to stress in the common diving petrel, Pelecanoides urinatrix. Physiol Zool 67:526-537.

Suorsa P., E. Huhta, A. Nikula, M. Nikinmaa, A. Jantti, H.
Helle, and H. Hakkarainen. 2003. Forest management is associated with physiological stress in an old-growth forest passerine. Proc R Soc B 270:963-969.

Tarlow E.M., M. Hau, D.J. Anderson, and M. Wikelski. 2003. Diel changes in plasma melatonin and corticosterone concentrations in tropical Nazca boobies (Sula granti) in relation to moon phase and age. Gen Comp Endocrinol 133:297304.

Wada H., K.G. Salvante, C. Stables, E. Wagner, T.D. Williams, and C.W. Breuner. 2008. Adrenocortical responses in zebra finches (Taeniopygia guttata): individual variation, repeatability, and relationship to phenotypic quality. Horm Behav 53:472-480.

Walker B.G., P.D. Boersma, and J.C. Wingfield. 2005. Field endocrinology and conservation biology. Integr Comp Biol 45:12-18.

Wasser S.K., K. Bevis, G. King, and E. Hanson. 1997. Noninvasive physiological measures of disturbance in the northern spotted owl. Conserv Biol 11:1019-1022.

Westerhof I., J.A. Mol, W.E. Van den Brom, J.T. Lumeij, and A. Rijnberk. 1994. Diurnal rhythms of plasma corticosterone concentrations in racing pigeons (Columba livia domestica) exposed to different light regimes, and the influence of frequent blood sampling. Avian Dis 38:428-434.

Whatley H.E., M.E. Lisano, and J.E. Kennamer. 1977. Plasma corticosterone level as an indicator of stress in the eastern wild turkey. J Wildl Manag 41:189-193.

Wikelski M. and S.J. Cooke. 2006. Conservation physiology. Trends Ecol Evol 21:38-46.

Wingfield J.C. and M. Ramenofsky. 1997. Corticosterone and facultative dispersal in response to unpredictable events. Ardea 85:155-166.

Wingfield J.C., J.P. Smith, and D.S. Farner. 1982. Endocrine responses of white-crowned sparrows to environmental stress. Condor 84:399-409.

Žydelis R., D. Esler, W.S. Boyd, D. Lacroix, and M. Kirk. 2006. Habitat use by wintering surf and white-winged scoters: effects of environmental attributes and shellfish aquaculture. J Wildl Manag 70:1754-1762. 
Copyright of Physiological \& Biochemical Zoology is the property of University of Chicago Press and its content may not be copied or emailed to multiple sites or posted to a listserv without the copyright holder's express written permission. However, users may print, download, or email articles for individual use. 